$$
\begin{aligned}
\text { 結晶性ポリマーの劣化挙動のマルチスケールモデリング† } \\
\text { 工藤 正和* 高橋 順一 }{ }^{*} \text { 山本 敏治* } \\
\text { 内田 真** 冨田 佳宏*** }
\end{aligned}
$$

\title{
Multi-scale Modeling of Degradation Behavior for Crystalline Polymer
}

\author{
by
}

\author{
Masakazu KUDO*, Junichi TAKAHASHI*, Toshiharu YAMAMOTO*, \\ Makoto UCHIDA** and Yoshihiro TOMITA***
}

\begin{abstract}
Coarse-grained molecular dynamics simulations are conducted, for the purpose of the study on the microscopic structure change of crystalline polymer due to degradation. Interlamellar structure changes are observed during the degradation, decreasing loop and bridge chains, increasing short tail chains. From the elongation simulation of lamellar structure, craze strength is dropped during the degradation, because of decreasing oriented interlamellar chains and drawing of the molecular chains from the crystal part. Multi-scale modeling is conducted to demonstrate the relationship between microscopic structure changes and macroscopic mechanical properties. As a result, macroscopic fracture strain is reduced by the degradation, because craze growth rate becomes faster with the degradation.
\end{abstract}

\section{Key words:}

Crystalline polymer, Degradation, Coarse-grained molecular dynamics, Multi-scale, interlamellar structures, Craze.

\section{1 緒言}

近年，ポリマーは材料自体の改質や強化材との複合化 により構造部材としての利用が拡大してきている．例え ば軽量化の手段として金属部品をポリマーで代替する場 合，成型時の初期物性は当然のことながら，長期信頼性 を有することも重要な性能となってくる。こうした点か らポリマーの経年劣化を予測し，予防することが急務と なっている.

従来のポリマーの研究を劣化の観点から整理すると, 主に二つの研究の流れに集約されるように思われる. 1 つ目は, 促進劣化試験に基づく寿命予測の研究 1),2)であり, ポリマーの使用環境を想定し，温度や紫外線により短時 間で長期間の劣化挙動の予測を試みたものである。様々 なポリマー材料での劣化予測が提案されているが，成型 条件が変わると同種の材料でも劣化の程度が変わること も報告 ${ }^{3)}$ されており, 前提条件を揃える必要がある.

2 つ目は，劣化反応を抑制し長寿命化を図る添加剤の 面からの研究である. 安定剤により効果的に劣化反応を 抑制するために，主に化学反応のプロセスに着目した研 究例が多い4),5). しかしながら，化学的な視点のため，反 応の結果として起こるモルホロジー変化や力学的な応答 の変化といった物理現象と直接結びつけることは難しい.

一方，ポリマーの微視的な構造から巨視的な機械的物 性を表現しようとする，いわゆるマルチスケールモデリ
ングの研究も盛んに行われている。冨田らは分子鎖網目 理論を拡張し，分子鎖の絡み点数の変化を許容した非ア フィンモデルを導入することで，ゴム材およびゴム材を 複合化したポリマーのヒステリシスロスやひずみ速度依 存性などの巨視的な力学応答の再現を可能としている 6),7),8). 内田ら ${ }^{9}$ は均質化法により, 結晶性ポリマーのラメ ラ構造を直接モデルに組み込むことでメゾスケールの球 晶の変形に関する有用な知見を得ている.

以上のように分子鎖構造と材料強度を結びつけた研究 例は多数報告されているが，ポリマーの劣化という視点 で微視的構造の経時変化と巨視的な機械的物性变化の関 係を検討した研究例はほとんど見られない。これは長期 に渡る構造変化を追跡することが困難なこと, 劣化の本 質が化学反応や物質拡散などの複雑な現象から成ること によるものと思われる。しかしながら，実験事実として 劣化により分子量や分子量分布の変化が起こることは数

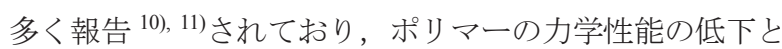
密接に関わっていると考えるのが自然である.このよう な劣化による分子構造の変化を数理的にモデル化するこ とが出来れば，前述のようなマルチスケールモデルに導 入することによって，非常に大きな時間と空間のスケー ルに適用可能な材料の機械特性の予測技術を確立するこ とができる。

以上の観点から本研究では, 長期間の劣化による変化

\footnotetext{
$\dagger$ 原稿受理 平成26年9月10日 Received Sep.10,2014 C2015 The Society of Materials Science, Japan

* 旭化成(株) 生産技術本部 生産技術センター CAE技術部 テ210-0863 川崎市川崎区

ASAHI KASEI CORPORATION, Kawasaki-ku, Kawasaki, 210-0863.

** 正 会 員 大阪市立大学大学院工学研究科機械物理系専攻 $=558-8585$ 大阪市住吉区

Department of Mechanical Engineering, Osaka City Univ., Sumiyoshi-ku, Osaka 558-8585.

*** 正 会員 神戸大学 $\bar{T} 651-2277$ 神戸市西区

Kobe Univ., Nishi-ku, Kobe 651-2277.
} 
を分子鎖の切断という現象として捉え，ポリマーの劣化 メカニズムを物理現象の面から明らかにすることを試み た. 結晶性ポリマーを対象として経年劣化を模擬した分 子鎖切断を与え，そのときの微視的構造変化を粗視化分 子動力学により検討した. さらに劣化によりクレイズの 生成状況が異なる点に着目し，クレイズ密度という物理 量で微視的構造変化と巨視的材料構成式を連結する新た なマルチスケールモデリング手法を提案した。

\section{2 微視的構造シミュレーション}

\section{$2 \cdot 1$ 初期構造のモデル化方法}

結晶性ポリマーは，微視的には分子鎖が規則的に整列 した結晶相とランダムに分布した非晶相の繰り返し構造 （ラメラ構造）から成っている. ラメラ構造のモデル化 方法は，屋代ら ${ }^{12)}$ のうに United Atom Model（炭素原子 に結合した水素原子を炭素原子と一体として取り扱うモ デル）により，結合角などの分子の化学的性質を保持し ながら詳細に構造をモデル化する方法が提案されている. 本研究では, 劣化による分子鎖切断が微視的構造のダイ ナミクスに与える影響を評価することを目的としたため、 ポリマーの鎖状に連結している性質を重視した。そのた め, 複数のモノマーを 1 つの質点として粗視化し, 質点 間の結合を非線形のバネで表現した Kremer-Grest 模型 ${ }^{13)}$ でモデル化した．本方法は化学的詳細を省き, 分子全体 の運動や分子間の相互作用による動力学を重視する場合 によく用いられるモデル化方法である．質点間のつなが りを表す結合ポテンシャル $U_{\text {bond }}$ は FENE+LJ ポテンシャ ル13)を使用した。

$$
\begin{gathered}
U_{\text {bond }}=U_{F E N E}+U_{L J} \\
U_{F E N E}=\left\{\begin{array}{c}
-\frac{1}{2} k R_{0}^{2} \ln \left[1-\left(\frac{r}{R_{0}}\right)^{2}\right], \text { if } r<R_{0} \\
\infty, \text { if } r \geq R_{0}
\end{array}\right. \\
U_{L J}=\left\{\begin{array}{c}
4 \xi\left[\left(\frac{\delta}{r}\right)^{12}-\left(\frac{\delta}{r}\right)^{6}+\frac{1}{4}\right], \text { if } r<2^{1 / 6} \delta \\
0, \text { if } r \geq 2^{1 / 6} \delta
\end{array}\right.
\end{gathered}
$$

ここで $U_{F E N E}$ は分子鎖伸長時の有限長さを表現するた めの引力項で, $U_{L J}$ は分子の衝突を避けるための乕力を表 現する項である. $k$ はバネ定数, $r$ は質点間距離, $R_{0}$ は最 大バネ長であり $, \delta, \xi$ である. 詳細は参考文献 13)を参照されたい.

結合していない質点間の相互作用（非結合ポテンシャ ル）は, レナードジョーンズポテンシャルを使用した。

$$
U_{\text {nonbond }}=\left\{\begin{array}{cr}
4 \bar{\xi}\left[\left(\frac{\bar{\delta}}{\bar{r}}\right)^{12}-\left(\frac{\bar{\delta}}{\bar{r}}\right)^{6}\right]+U_{\text {cutoff }}, & \text { if } \quad \bar{r}<r_{c} \\
0 & \text {, if } \bar{r} \geq r_{c}
\end{array}\right.
$$

質点間の相互作用は有限範囲とし, カットオフ距離 $r_{c}$ 以上の引力計算を打ち切り, カットオフ距離でポテンシ ヤルが 0 になるように補正項 $U_{\text {cutoff }}$ を加えた.

本研究ではポリプロピレンの結晶内部の周期単位 $\left[\mathrm{C}_{3} \mathrm{H}_{6}\right]_{3}$ の原子団を 1 つの質点とした粗視化を行った. 解 析に使用したポテンシャルパラメータを Table1 に示す.

Table 1 Potential parameters for polypropylene model.

\begin{tabular}{c|c}
\hline$k\left[\mathrm{~kJ} /\left(\mathrm{mol} / \mathrm{nm}^{2}\right)\right]$ & $2.041 \times 10^{3}$ \\
$R_{0}[\mathrm{~nm}]$ & 0.908 \\
$\delta, \bar{\delta}[\mathrm{nm}]$ & 0.605 \\
$\xi, \bar{\xi}[\mathrm{kJ} / \mathrm{mol}]$ & 68.0 \\
$r_{c}[\mathrm{~nm}]$ & 0.787 \\
\hline
\end{tabular}

初期構造の作成には OCTA ${ }^{14)}$ の汎用粗視化分子動力学 ソフトCOGNACを使用した. OCTA はポリマーの材料設 計を目的とした異なるスケール間のズーミングを可能と するオープンソースのプログラム群である. ズーミング 機能の一つとして開発された Lamellar generator は, 平均 場理論により計算された結晶間非晶相（インターラメラ） の分子鎖存在確率に従い, ラメラ構造を発生させる機能 である. 詳細はマニュアル ${ }^{14)}$ を参照されたい.

ラメラ初期構造は周期境界条件を与えた $9.7 \mathrm{~nm} \times 9.7 \mathrm{~nm}$ $\times 12.1 \mathrm{~nm}$ の直方体セル中に分子鎖を発生させることによ り得た．分子鎖 1 本は 1200 個の質点が結合された鎖でモ デル化した. 分子量に換算すると $\mathrm{M}=50400$ となる. 分子 鎖 4 本をセル中に発生し, ラメラの C 軸方向の結晶相長 さを $9.1 \mathrm{~nm}$, 非晶相長さを $3.0 \mathrm{~nm}$ とした. 結晶相, 非晶相 の密度はそれぞれ $0.94,0.75 \mathrm{~g} / \mathrm{cm}^{3}$ に設定した。

上記条件で分子鎖を発生させた後，NVE アンサンブル で $1.359 \mathrm{~ns}$ 構造緩和させ, 内部エネルギの平衡化を行った. 温度は $300 \mathrm{~K}$ とし，13.59ps ごとに速度スケーリングを行 い制御した。 こうして得られた初期構造を Fig.1 に示す. 分子鎖（結合ポテンシャル）は線で表示した. 分子が一 方向に整列した結晶相とランダムに絡み合った非晶相か ら成り, ラメラ構造が再現されていることがわかる。

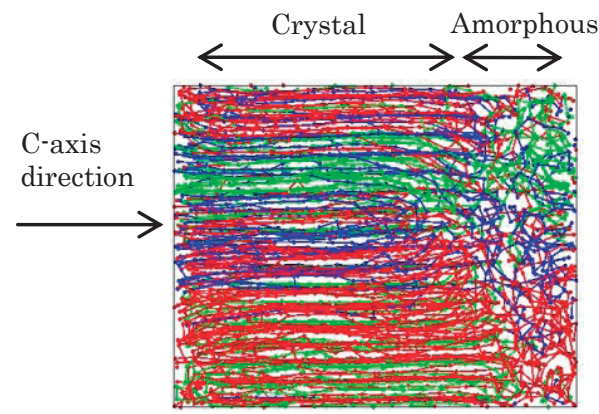

Fig. 1 Snapshot of initial lamella structure (No degradation).

$2 \cdot 2$ 劣化による微視的構造変化のシミュレーション 一般的に，ポリマーの劣化による構造変化は，酸化反 応によって生成したラジカルの $\beta$ 開裂反応に起因する主 鎖の切断と考えられている ${ }^{15)}$. 結晶性ポリマーの場合は, 酸素の拡散が非晶部に限られるため, 劣化は主として非 
晶部の分子鎖切断という形で現れる。したがって，初期 形状のラメラモデルの非晶部の結合をランダムに解離す ることで劣化を表現することとした．劣化による分子鎖 切断数は，酸化反応速度と経過時間で関係づけられるが, 反応速度の推定が困難なため, 実時間との対応は行わず, 分子鎖の切断を確率過程で置き換える。具体的には，非 晶部に存在する質点を全てリストした後，ランダム関数 を使用して無作為に質点を選択する，選択した質点に結 合するポテンシャルを削除することで結合の解離を行っ た. 結合解離が非晶部の質点総数の $10 \%$ に達するまで段 階的にこの工程を繰り返した。結合を解離したモデルは，

2.1 節と同じ手続きで，構造緩和を行った。

ここで非晶相の劣化による構造変化を評価するために, 非晶相に存在する分子鎖の形態を Fig. 2 のように分類する. 同一の結晶相に戻る鎖を(a)ループ鎖，結晶間を結ぶ鎖を (b)ブリッジ鎖，末端が非晶相に存在するものを(c)テール 鎖, 鎖が結晶相に属さないものを(d)フリー鎖と定義する.

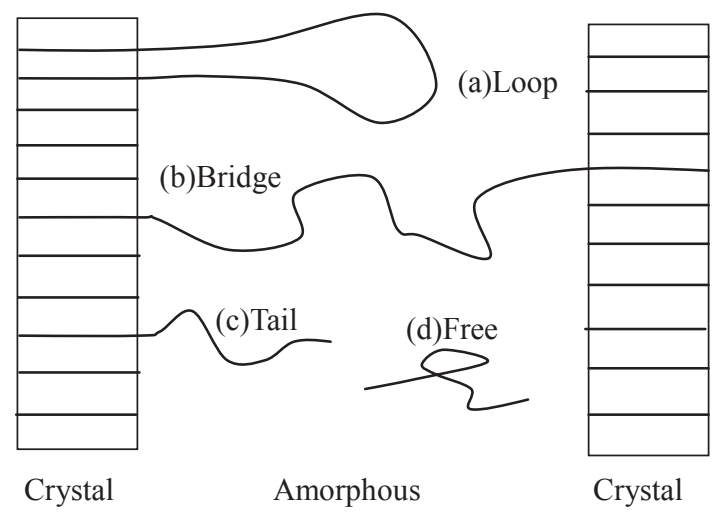

Fig. 2 Schematic diagram of chains in amorphous region.

Fig.3 に劣化による非晶相の各分子鎖の成分の変化を示 す。但し，テール鎖とフリー鎖は結晶間の力の伝達に寄 与しないため，分類はしていない。劣化がない初期構造 では，鎖長の長いブリッジ鎖やループ鎖が存在し，テー ル鎖はほとんど見られない。劣化が進むにつれ，ブリッ ジ鎖とループ鎖は鎖長が短くなり，鎖の数自体も減少す る。一方，鎖長の短いテール鎖，フリー鎖の割合が劣化
に従い急増するということが分かる。

劣化がない場合と劣化 $10 \%$ の場合のセルのスナップシ ヨットを Fig.4 に示す. 質点の非結合ポテンシャルが作用 する範囲を球で表現した。劣化 $10 \%$ の場合に，非晶部に わずかにボイドが発生しているのが確認できる。これは セルの体積を不変としたために，劣化によって生成した テール鎖，フリー鎖が凝集した結果，ボイドとして観察 されたと考えられる.

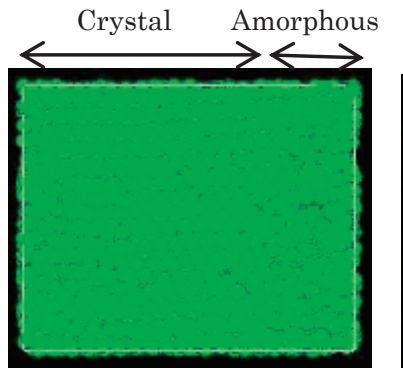

No degradation (No chain scission)

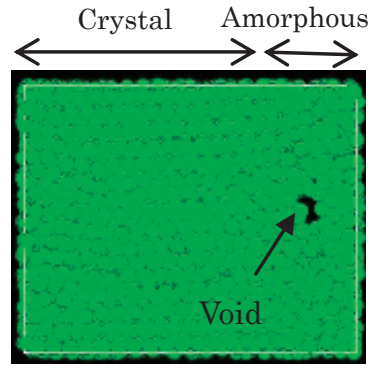

Severe degradation ( $10 \%$ chain scission $)$
Fig. 4 Snapshot of lamella structure in the case of $10 \%$ amorphous chain sccision.

\section{$2 \cdot 3$ 劣化による微視的な力学応答変化}

次に各劣化段階のラメラモデルに伸長変形を与えて力 学的な応答の変化を観察した。伸長変形はセルの C 軸方 向にひずみ速度 $3.679 \times 10^{9} \mathrm{~s}^{-1}$ の一定速度で与えた. ポテン シャルパラメータは $2 \cdot 2$ 節と同じものを用いた。

Fig.5 に伸長変形の各ひずみでのスナップショットを示 す. 劣化のないモデルではセル変形により, 非晶相の分 子鎖が引き伸ばされ，延伸方向に配向したフィブリルと ボイドが形成される $(\varepsilon=0.5)$. その後配向した分子鎖は束 になり，結晶相から鎖が引き抜かれながら安定して成長 する $(\varepsilon=0.8 \sim 2.0)$. このように, 非晶相において空間が発 生し, それが広がっていく現象は結晶性ポリマーの破壊 過程で観察されるクレイズ ${ }^{16)}$ の様相に酷似している.

一方，劣化を受けた組織でも同様にクレイズ状の空間 の形成が観察されるが，Fig.3 で示したように結晶間を結

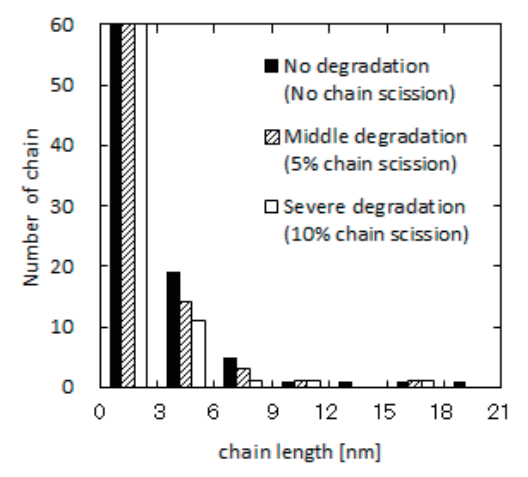

(1) Loop

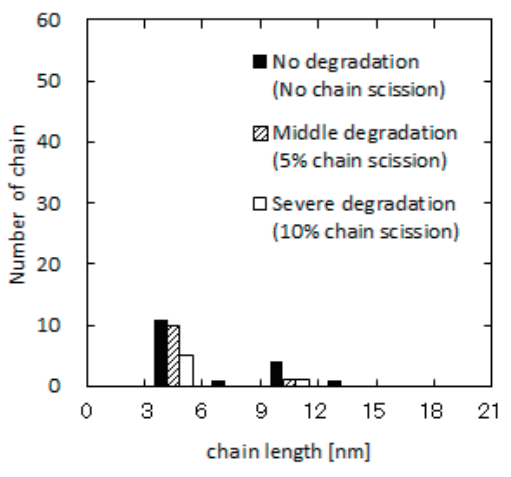

(2) Bridge

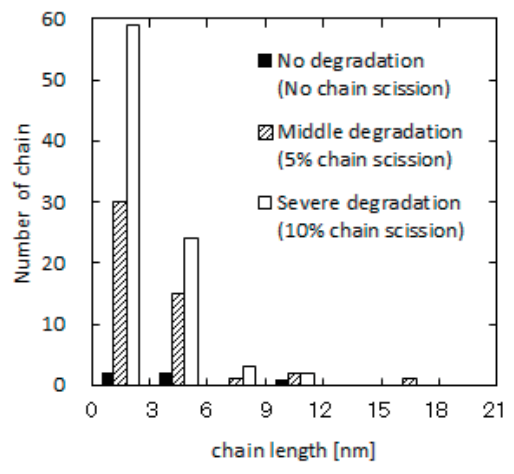

(3) Tail and Free

Fig.3 Changes of amorphous chains structure caused by degradation. 

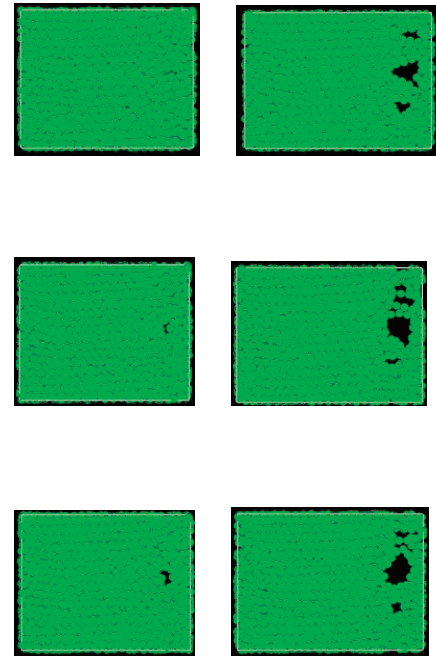

$\varepsilon=0.0$

$\varepsilon=0.1$
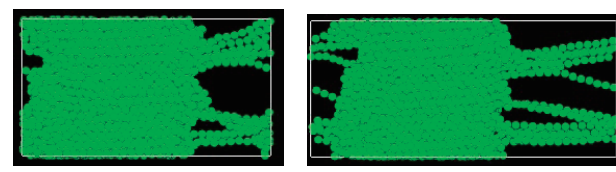

(a)No degradation (No chain scission)
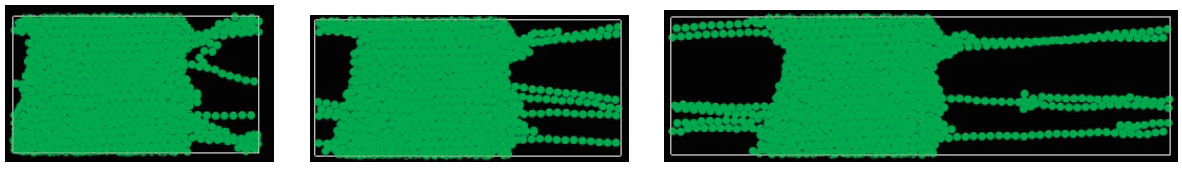

(b)Middle degradation ( $5 \%$ chain scission)
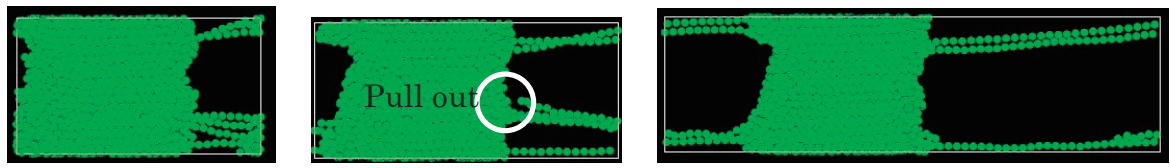

(c)Severe degradation (10\% chain scission)

$\varepsilon=0.5 \quad \varepsilon=0.8$

$\varepsilon=2.0$

Fig. 5 Snapshots of elongation process of lamella structure.

ぶブリッジ鎖が減少するため，非晶部で配向する分子鎖 の数は劣化が進むほど少なくなる $(\varepsilon=0.5)$. 角岡 ${ }^{17)}$ は結晶 間を結ぶブリッジ鎖が劣化により切断することで脆化す ると指摘しており，この機構を裏付ける結果となってい る。また，延伸が進むと配向した分子鎖が結晶相から完 全に引き抜かれてテール鎖となることで，ブリッジ鎖の 本数がさらに減少する $(\varepsilon=0.8 \sim 2.0)$. これは, 劣化による ループ鎖の切断により，分子量が小さくなり，結晶相か ら引き抜かれやすくなるためだと考えられる.

伸長シミュレーションによる C 軸方向の応力ひずみ関 係を Fig. 6 に示す。ひずみ 0.1 程度までは共通して応力 の低下が見られるが，これは非晶部にボイドを形成する

(Fig. $5 \varepsilon=0.1)$ ためだと考えられる. その後，劣化のな い条件では，ひずみ 0.8 付近から応力の上昇が観察され る。これは非晶部の分子鎖が配向して質点間のバネが引

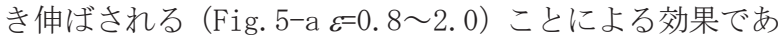
ると考えられる。一方，劣化条件下では，同様にひずみ 0.1 程度まで応力が低下寸るが, 応力低下の度合いは劣化 の程度が大きいほど大きい。これは劣化により結晶間の 力の伝達を担うブリッジ鎖が減少する（Fig. $5 \varepsilon=0.5 ） た$ めだと理解される。劣化条件下でさらに延伸が進むと劣 化なしの場合と異なり，徐々に応力が下がり続ける．特 に劣化 $10 \%$ ひずみ 0.8 付近で大きく応力が低下している 点に注目すると, Fig. $5-\mathrm{c} \varepsilon=0.8$ に示すように分子鎖の結 晶相からの引き抜きが観察される。したがって，劣化条 件下でひずみの増加に従って応力が低下寸るのは分子鎖 の引き抜きにより，結晶間の力を伝達するブリッジ鎖が さらに減少するためだと考えられる。杉本ら ${ }^{18)}$ は，実験 的検討からポリプロピレンのクレイズ強度が分子量に依 存することを明らかにしており，劣化に起因する非晶部 の分子鎖切断が分子量（鎖の平均モノマー数）の低下を
もたらし，フィブリルの強度低下を招くという本研究の 知見と同じ傾向を示寸。

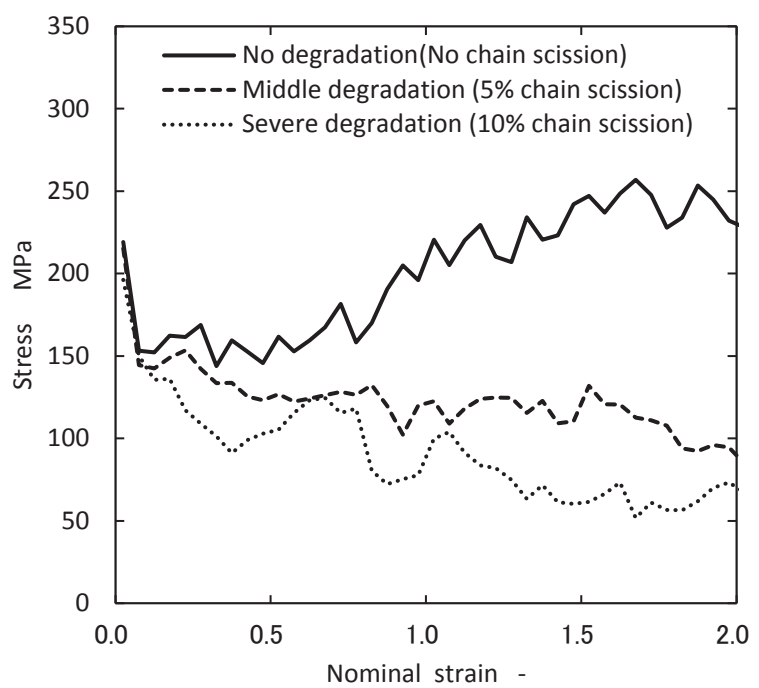

Fig. 6 Stress -Strain curves.

\section{$3 \cdot 1$ クレイズ発展式}

3 劣化のマルチスケールモデリング

劣化による巨視的な物性の予測には，高橋ら ${ }^{19)}$ の弾粘 塑性構成式を用いた。この式の特徵として，ポリマーの 破壊挙動を予測するため，微視的な損傷であるクレイズ 密度の蓄積の効果を考慮している点が挙げられる．本研 究では, 粗視化分子動力学の検討により明らかになった 劣化によるクレイズ生成状況の違いに着目し, 高橋らの 提案するクレイズ発展式の同定を行った。これにより， クレイズ密度という物理量を介して，異なるスケール間 を連結し，劣化のマルチスケールモデリングを可能とし た. 
以下に高橋ら ${ }^{19)}$ のクレイズ発展式の微視的シミュレー ションによる同定方法を示す，簡単のため，ひずみ速度 依存性は考慮しないこととすると, クレイズ進展速度 $\dot{\omega}$ は式(5)のように単純化できる.

$$
\dot{\omega}=\frac{A}{4}\left[1+\tanh \left\{-D_{3}\left(\bar{\varepsilon}^{p}-\varepsilon_{c}\right)\right\}\right] \dot{\bar{\varepsilon}}^{p}
$$

$\bar{\varepsilon}^{p}$ は相当塑性ひずみ, $\dot{\bar{\varepsilon}}^{p}$ は相当塑性ひずみ速度であ る。 $\varepsilon_{c}$ は成長停止ひずみで，式(5)はクレイズが一定のひ ずみ以上で成長速度が小さくなることを表現している． $A$, $D_{3}$ は無次元係数で，それぞれクレイズの成長速度の大き さとクレイズ成長速度の鈍化具合を表す係数である.

ここでクレイズ密度 $\omega$ をボイド率と置き換え， $2 \cdot 3$ 節 のラメラ構造の延伸シミュレーションから相当塑性ひず み $\bar{\varepsilon}^{p}$ とボイド率 $\omega$ の関係を求めたものを Fig.7 に示す. ク レイズ密度(ボイド率)は体積分率で定義される量だが，こ こでは簡単のため面積率で規定することとし，代表的な ひずみでのスナップショットから画像処理によりボイド の面積率を求めた. Fig.7 から劣化の程度が大きくなると ボイドの成長が速くなることが分かる，さらにひずみが 大きくなると成長速度が小さくなる傾向が表れており， 式(5)のクレイズの成長停止を表す関数でフィッティング することが可能である。同定したパラメータセットを Table2 に示寸。本研究では既に提案されたクレイズ発展 式のパラメータ同定を行ったが，経過時間を変数とする ような関数でクレイズ発展式を表現した方が汎用性は高 く, 産業利用上有用である。この点については次報への 課題としたい.

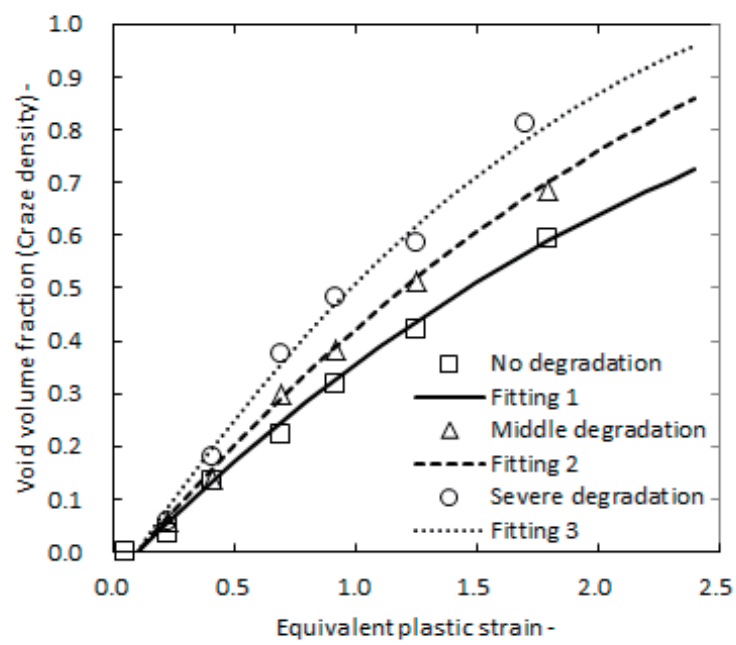

Fig.7 Relationship between void volume fraction and equivalent plastic strain.

\begin{tabular}{c|c|c|c} 
Table 2 & \multicolumn{3}{c}{ Craze parameters. } \\
& $A$ & $D_{3}$ & $\varepsilon_{\mathrm{c}}$ \\
\hline (1)No degradation & 1.6 & 0.3 & 0.5 \\
(2)Middle degradation & 1.9 & 0.3 & 0.5 \\
(3)Severe degradation & 2.3 & 0.4 & 0.5 \\
\hline
\end{tabular}

\section{$3 \cdot 2$ 巨視的な力学応答シミュレーション}

同定したパラメータを用いてポリプロピレンの平板の 単軸引張シミュレーションを行い, 巨視的な力学特性の 変化を確認した。クレイズ発展式以外の条件（構成式, パラメータ, FEM モデル，拘束条件など）は高橋らの文 献 ${ }^{19)}$ と同様とし, 限界クレイズ密度を 0.6 として破断判定 を行った. Fig.8 にシミュレーション結果得られた応力ひ ずみ関係を示す。

劣化が進むにつれてクレイズの成長速度が速くなるた め, 破断クレイズ密度に早く到達し, 破断ひずみが減少 する傾向を示す。これは，和田ら ${ }^{20)}$ が報告したポリプロ ピレンを硝酸溶液に浸漬した場合の，浸漬時間に依存し て破断ひずみが低下寸る現象と対応する結果となってい る.また和田らはU 字型切欠き試験片の 3 点曲げ試験に よって, 硝酸に浸漬したホモ PP の試料表面でクレイズの 発生とクラックへの転化を確認しており，硝酸による試 料表面の分子量の低下がクレイズ強度の低下をもたらし たと結論づけている。実験で観察されたクレイズは Fig.5 で示した変形形態に類似している.さらに，式(5)には陽 に表されていないが, 分子量の低下の効果は, クレイズ の成長速度という形で考慮されており, 分子量の低下が クレイズ強度の低下を招くという点でも和田らの実験を 再現する結果となっている。 また, 硝酸液は試料表面の 非晶部から内部に拡散すると考えられ，Fig.5 にみられる ような変化が試料表面で顕在化したことも理解できる結 果である。

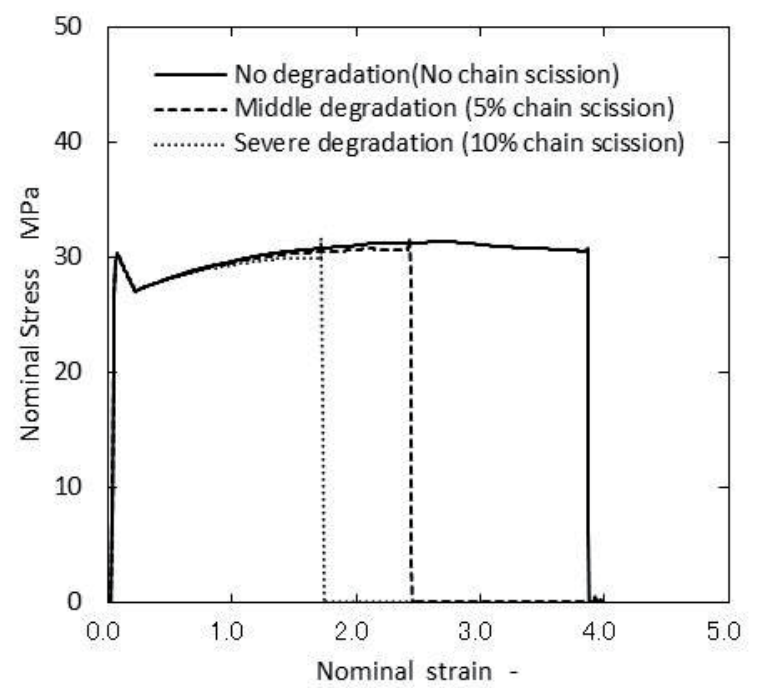

Fig.8 Stress strain curves of PP plate under uniaxial tension.

\section{4 結言}

結晶性ポリマーの微視的構造を粗視化分子動力学モデ ルを用いて構築し, 劣化時の構造変化と力学応答につい て検討した。 さらにマルチスケールモデリングにより, 劣化時の巨視的な物性変化の予測を試みた。本検討から 結晶性ポリマーの劣化に関して以下のような知見が得ら れた。 
(1)劣化による非晶相の分子鎖切断により, ループ鎖，ブ リッジ鎖の割合の減少と, 鎖長の短いテール鎖, フリー 鎖の割合の急増を伴った構造変化が起こった. その結果, 非晶相で分子鎖が凝集し, ボイドの生成などの構造変化 が起こることが明らかになった。

(2) 結晶構造が延伸されると, 劣化によってブリッジ鎖が 減少するため, 非晶部で配向する分子鎖も減少した. 加 えて劣化により分子量が低下寸るため, 結晶相からの分 子鎖引き抜きが起こり易くなり, クレイズ強度の低下を もたらした.

(3)劣化によりクレイズの生成状況が異なる点に着目し, クレイズ密度という物理量で微視的構造変化と巨視的 な材料構成式を連結する手法を提案した. 本手法を用い てポリプロピレンの劣化挙動について検討した結果, 劣 化による分子量の低下がクレイズの成長速度の増加を もたらし，巨視的には破断ひずみの減少を招くという実 験の傾向を再現する結果が得られた。

神戸大学計算科学教育センターの賀谷先生，小柳先生 には技術的な指導や計算環境の提供などで多大なご支援 を賜りました。ここに感謝の意を表します。

粗視化分子動力学の計算には OCTA $(<\mathrm{http}: / /$ octa.jp $>)$ を 使用させて頂きました。ここに記して謝意を表します。

\section{参 考 文 献}

1) G. Steiner and J. Koppelmann, "Mesurement of thermo-oxidative stability of isotactic polypropylene by isothermal long-term differential thermal analysis", Polymer Degradation and Stability, Vol.19, Issue 4, pp.307-314 (1987).

2) A. S. Maxwell. W. R. Broughton, G. Dean and G. D. Sims, "Review of accelerated ageing methods and lifetime prediction techniques for polymeric materials", NPL Report DEPC MPR 016 (2005).

3) S. Nishimoto, "Degradation assessment in relation to morphology", Materials Life, Vol.2, No.4, pp.199-206 (1990).

4) S. Matsumura, H. Kasama, K. Asakura and S. Yoshikawa, "Polymeric antioxidants. III. polyvinylphenol", Journal of Japan Oil Chemists, Vol.37, No.8, pp.654-658 (1988).

5) S. Yachigo, M. Sasaki, Y. Takahashi, F. Kojima and T. Takada, "Studies on polymer stabilisers: part I - a novel thermal stabiliser for butadiene polymers", I Polymer Degradation and Stability, Vol.22, Issue 1, pp.63-77 (1988).

6) Y. Tomita, "Modeling and simulation of deformation behavior of polymer based on molecular chain network theory I: constitutive equation for polymer based on molecular chain network theory", Journal of the Society of Materials Science, Japan, Vol.62, No.7, pp.465-471 (2013).

7) Y. Tomita, "Modeling and simulation of deformation behavior of polymer based on molecular chain network theory II: evaluation, strengthening and functionalization of multi phased polymer", Journal of the Society of Materials Science, Japan, Vol.62, No.8, pp. 531-536 (2013).

8) Y. Tomita, "Modeling and simulation of deformation behavior of polymer based on molecular chain network theory III: evaluation and prediction of texture formation of crystalline polymer and micromechanical simulation", Journal of the Society of Materials Science, Japan, Vol.62, No.9, pp. 598-604 (2013).

9) M. Uchida and Y. Tomita, "Micro- to mesoscopic deformation behavior of spherulite of semi-crystalline polymer", Transactions of the Japan Society of Mechanical Engineers Series A, Vol.72, No.717, pp.608-615 (2006).

10) F. Ebisawa, M. Hoshino and Y. Sato, "Mechanism of polyethylene photodegradation studied by molecular weight and molecular weight distribution measurements", KOBUNSHI RONBUNSHU, Vol.36, No.12, pp. 791-795 (1979).

11) M. Kitamura, T. Tanaka, T. Kuriyama, E. Miyagawa, A. Tanaka and N. Kawabata, "Heat degradation of poly(propylene) in extruding cycles", Resources Processing, Vol.51, No.2, pp.77-82 (2004).

12) K. Yashiro, T. Ito and Y. Tomita, "Molecular dynamics study on deformation behavior of molecular chains at crystal / amorphous interface in polymers", Transactions of the Japan Society of Mechanical Engineers Series A, Vol.70, No.693, pp.696-702 (2004).

13) K. Kremer and G. S. Grest, "Dynamics of entangled linear polymer melts: a molecular dynamics simulation", The Journal of Chemical Physics, Vol.92, No.8, pp5057-5086 (1990).

14) http://octa.jp

15) Z. Osawa, "Koubunshi rekka choujumyouka handbook", pp.6-15(2011), Maruzen.

16) N. Tsuruta, Y. Tsuge, T. Maeda, T. Nakaoki and H. Hayashi, "Micromechanism of fracture in engineering plastics", Japanese Journal of Polymer Science and Technology, Vol.54, No.4, pp. 199-208 (1997).

17) M. Tsunooka, "Mechanism of polymer degradation", Journal of the Society of Rubber Science and Technology, Japan, Vol.68, No.5, pp. 274-283 (1995).

18) M. Sugimoto, M. Ishikawa and K. Hatada, "Toughness of polypropylene”, Polymer, Vol.36, No.19, pp.3675-3682 (1995).

19) J. Takahashi, T. Yamamoto and K. Shizawa, "A simulation for ductile fracture prediction of crystalline polymer based on craze behaviour (A model for propagation and growth cessation of craze and analysis with a commercial FEM solver)", Transactions of the Japan Society of Mechanical Engineers Series A, Vol.76, No.764, pp.473-482 (2010).

20) H. Wada and M. Ishikawa, "Degradation mechanism and stabilization of polypropylene induced by chemical solutions", Japanese Journal of Polymer Science and Technology, Vol.63, No.6, pp.383-389 (2006). 